\title{
Clear Cell Meningioma
}

National Cancer Institute

\section{Source}

National Cancer Institute. Clear Cell Meningioma. NCI Thesaurus. Code C4722.

A WHO grade II morphologic variant of meningioma characterized by the presence of clear glycogen-rich polyg onal cells. 